\title{
Determination of S1 screw adjustment parameters using by 3D CT images in healthy subjects
}

\section{Sağlıklı bireylerde 3D BT görüntüleme kullanılarak S1 vida parametrelerinin belirlenmesi}

\author{
Mehmet Hüseyin Akgül ${ }^{*}$ (D), Veysel Burulday ${ }^{2}(\mathbb{D})$, Mustafa Öğden ${ }^{3} \mathbb{D}$, Ulaş Yüksel ${ }^{4}$ \\ ${ }^{1}$ Kırıkkale Yuksek Ihtisas Hospital, Department of Neurosurgery, Kırıkkale, Turkey \\ ${ }^{2}$ Kırıkkale University, Faculty of Medicine, Department of Radiology, Kırıkkale, Turkey \\ ${ }^{3}$ Kırıkkale University, Faculty of Medicine, Department of Neurosurgery, Kırıkkale, Turkey \\ ${ }^{4}$ Ankara Yenimahalle State Hospital, Department of Neurosurgery, Ankara, Turkey \\ * Corresponding author: Mehmet Huseyin Akgül E-mail: dr_mhakgul@yahoo.com ORCID: 0000-0001-5966-3042 \\ Received: 30 July 2018 Accepted: 16 November 2018
}

\begin{abstract}
Background: The aim of this study was to investigate the anthropometry of the posterior superior iliac spine (PSIS) types in the Turkish population and to determine the safe limits of the length and angle of the sacrum by the posterior lumber approach in lumbosacral instrumentation surgery.

Material and Method: Sacral regions (left and right pedicle lengths and pedicle angles) and PSIS types of healthy subjects were evaluated using 3D images.

Results: A total of 111 patients ( 58 males and 53 females) were included in the study. The mean age was $46.9 \pm 14.8$ in males and $44.3 \pm 16.4$ in females. In men, the right pedicle length was $52.83 \mathrm{~mm}$, the left pedicle length was $53.81 \mathrm{~mm}$, the right pedicle angle was 35.84 , the left pedicle angle was 35.13 , and the caudal angle was 39.24 degrees. In females, right pedicle length was $48.88 \mathrm{~mm}$, left pedicle length was $49.28 \mathrm{~mm}$, right and left pedicle angle was 35.83 , and caudal angle was 39.24 degrees. PSIS type 1 was found to be $58.6 \%$, type $232.4 \%$ and type $39 \%$.

Conclusion: Optimal screw lengths, angles and proper screw orientations can be easily and safely operated in posterior stabilization. In this study, morphometric and anthropometric information related to sacral screw orientation were also determined. These data may help to prevent surgical complications by contributing to the surgeon about preoperative anatomical structure in lumbosacral surgery stabilization procedures.
\end{abstract}

Keywords: bone, screw, sacroiliac joint, sacrum

() 2019 by the authors; licensee MEDITAGEM Ltd., Turkey. This article is an open access article distributed under the terms and conditions of the Creative Commons Attribution License (http://creativecommons.org/licenses/by/4.0/). 


\section{ÖZ}

Amaç: Bu çalışmanın amacı posterior superior iliak omurga (PSIO) tiplerinin antropometrisini Türk toplumunda araştırmak ve lumbosakral enstrümantasyon cerrahisinde posterior lumber yaklaşım ile sakrumun uzunluğunun ve açısının güvenli sınırlarını saptamaktır.

Gereç ve Yöntem: Sağlıklı bireylerde sakrum'un sol-sağ pedikül uzunlukları, pedikül açıları ve PSIS tipleri 3 boyutlu görüntüler kullanılarak değerlendirildi.

Bulgular: Çalışmaya 58'i erkek, 53'ü bayan toplam 111 kişi alındı. Ortalama yaş erkeklerde 46,9 \pm 14,8, kadınlarda 44,3 \pm 16,4 idi. Erkeklerde sağ pedikül uzunluğu 52,83 mm, sol pedikül uzunluğu 53,81 mm, sağ pedikül açısı 35,84, sol pedikül açısı 35,13 , kaudal açı 39,24 derece olarak saptandı. Kadınlarda ise sağ pedikül uzunluğu 48,88 mm, sol pedikül uzunluğu 49,28 mm, sağ ve sol pedikül açısı 35.83, kaudal açı 39,24 derece idi. PSIO tip 1 \% 58,6, tip 2\%32,4, tip 3 \%9 oranında saptandı.

Sonuç: Posterior stabilizasyonda sakral vidalamada optimal vida uzunlukları, açıları ve uygun vida oryantasyonlarının preop yapılması ile operasyon kolay ve güvenli olabilir. Bu çalışma ile aynı zamanda sakral vida oryantasyonu ile ilgili morfometrik ve antropometrik bilgiler de saptanmıştır. Bu veriler lumbosakral cerrahi stabilizasyon işlemlerinde preop anatomik yapı hakkında cerraha katkı sağlayarak cerrahi komplikasyonları önlemede yardımcı olabilecektir.

Anahtar kelimeler: kemik, vida, sakroiliak eklem, sakrum

\section{INTRODUCTION}

Surgical interventions to the sacrum require a good anatomical knowledge because of its various pedicle angles and anteroposterior diameters (i.e. Posterior superior iliac spine (PSIS) types). The main purpose of lumbosacral instrumentation systems is to limit the movement of this segment, prevent sacroiliac joint movement, preserve lumbosacral angle and stabilize the spine [1-3]. It has been demonstrated that $\mathrm{S} 1$ pedicle screw installation is an important goal for posterior lumbosacral instrumentation. However, sacral screw fixation may fail due to the small body of the S1 spine, difficult orientation angle of sacral pedicle, small subcortical structure of the sacral bone, and anatomical variations of posterior superior iliac spine (PSIS) defined as open, closed and borderline types. So, stabilization of the lumbosacral region is still difficult procedure, today [4-7].

The aim of this study was to evaluate the morphometric characteristics of the sacrum which provide to determine its safe margins of the sacral pedicle lengths and antero-medial angles, and caudal angles of the sacrum for lumbosacral screw fixation.

\section{MATERIAL AND METHOD}

\section{Materials}

This retrospective study was conducted by evaluating the sacral CT images and the ethical approval was obtained from the Local Ethical Committee.
The participants of study group were choosen from 18-65 year-old (A total of 111 patients '58 males and 53 females' were included in the study) healthy volunteers who were admitted to the Radiology Department between October 2015 and January 2016. The participants who did not underwent sacral or lumbosacral surgery and/ or did not have lumbosacral pathology (mass lesion, infection) were included into this study to evaluate the sacrum CT images. The CT images were obtained by using 64-slice $C T$ (Philips Medical System, Brillance 64, Best, Netherlands).

\section{Methods}

All sacrum CT screenings were routinely performed in supine position, and neither contrast medium nor anaesthetic agent was given to the subjects. All screenings were obtained using the following parameters:

tube voltage: $120 \mathrm{kV}$;effective mAs: 350;section thickness: 3 $\mathrm{mm}$; view: $300 \mathrm{~mm}$ (FOV), screening field of $768 \times 768$ image matrix, radiation dosage was $626,8 \mathrm{mGy}$.

The first images were obtained in the axial plain and subsequently reconstruction was performed onto the raw data. These measurements were made on 3-dimensional (3D) images.

Firstly, images of the axial neutral position of S1 were obtained by using the sacrum 3D CT scan. Then the sacrum pedicle orientations were classified in three categories according to PSIS (i.e. PSIS type or "sacrum type") as following: 


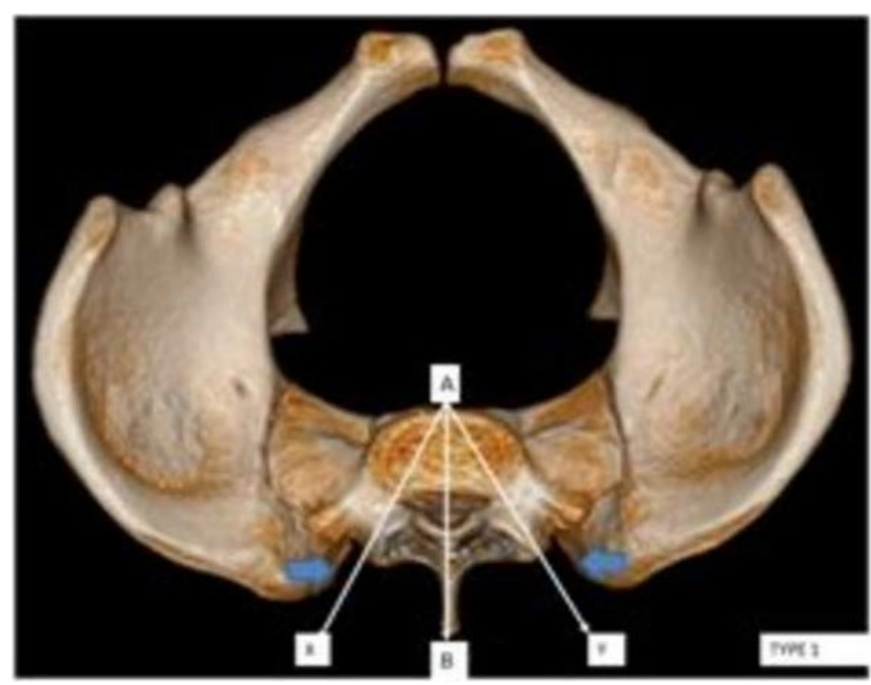

Figure 1. This figure shows the right side $A X$ plane and the left side AY plane of pedicle screw orientations on the sacrum. Blue arrow does not appear to touch the PSIS of the screw plane orientation. (PSIS Type 1)

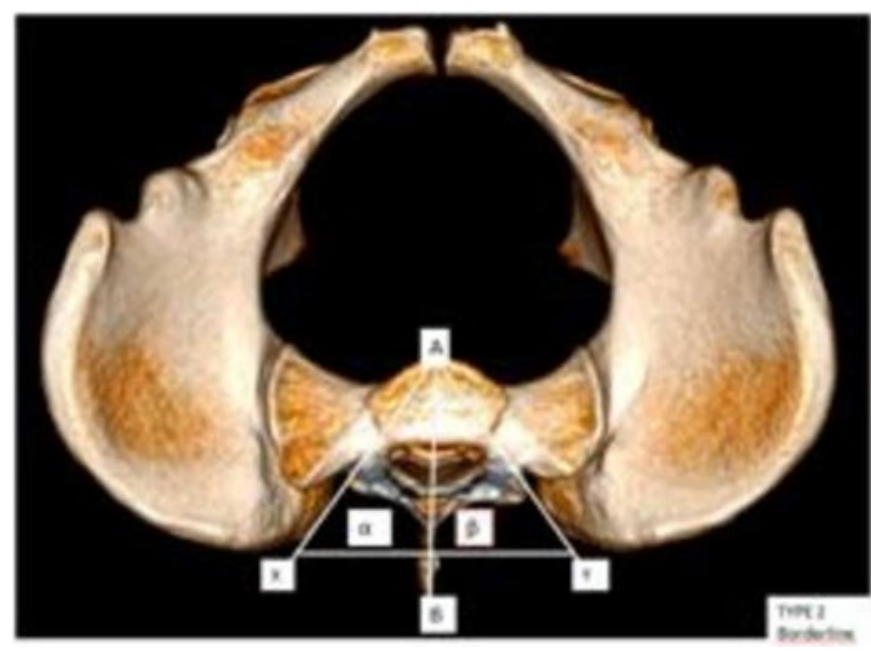

Figure 2. This figure shows the alpha angle $(X A B)$ and the beta angle (YAB). AX and AY plane does appear to touch the PSIS of the screw plane orientation. (PSIS Type 2 border line)

- PSIS type 1 was defined as those in which no screw orientation difficulty was encountered.

- PSIS type 2 was defined as those between type 1 and type 3.

- PSIS type 3 was defined as those in which screw orientation could not be lateralized in the axial plane due to closure of the screw entry.

The entry point of $S 1$ pedicle screw was defined as the $Y$ point in the left side pedicle and the $X$ point in the right side pedicle. The termination point of the pedicle screw was defined as the A point located at the medial, superior, anterior margin of the sacrum (called promontorium). $B$ line was defined as the midline plain of the sacrum anteroposteriorly. The distance between the A point and the

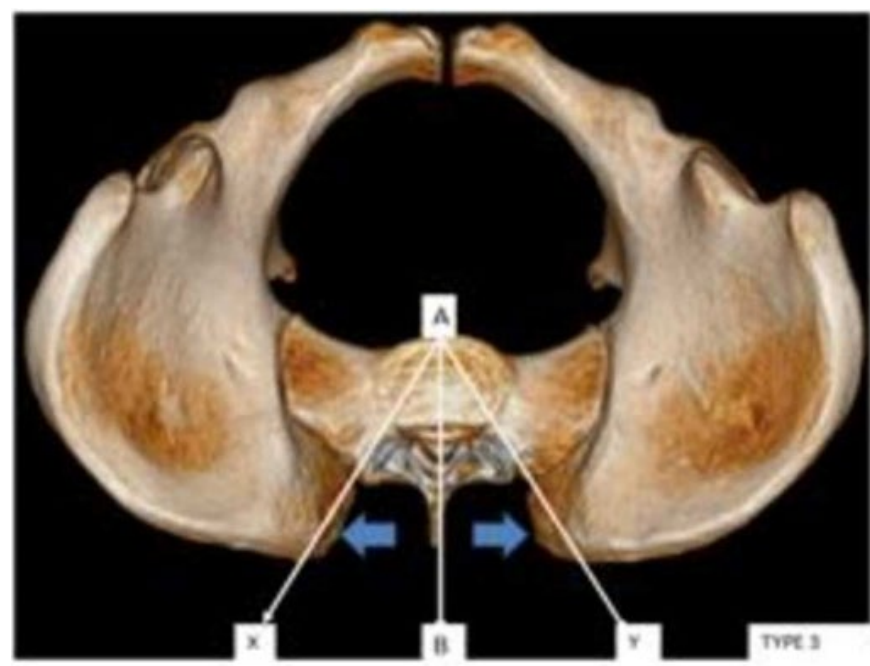

Figure 3. This figure shows that the blue arrow passed through the iliac wing of $A X$ and $A Y$ plane. (PSIS type 3 )

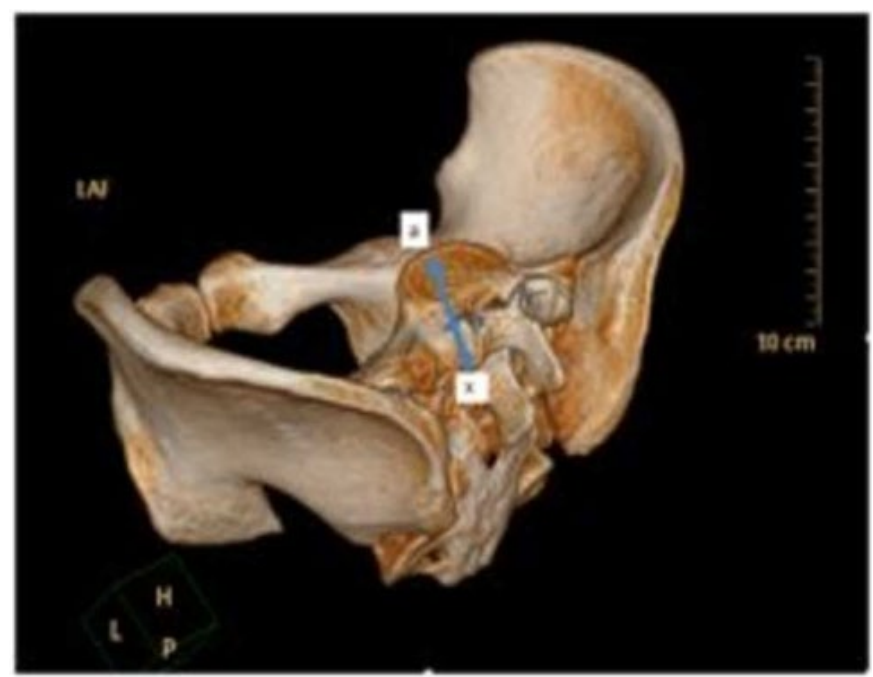

Figure 4. This figure shows the shape of the screw orientation in the right $\mathrm{AX}$ plane with the blue arrow

$X$ point (i.e. "right pedicle length"), and between the Apoint and the $Y$ point (i.e. "left pedicle length") was defined as the sacral screw length. If the linear plane of AX or AY did not touch the margin of PSIS in posterior, it was defined as type 1 (Figure 1), and if this plain touched the margin of PSIS, it was defined as type 2 (borderline) (Figure 2) and if this plain went over PSIS, it was called type 3 (Figure 3).

In addition, the angle between points $X-A-B$ was taken as the right sacral screw orientation angle called "right pedicle angle", and the angle between points $\mathrm{Y}-\mathrm{A}-\mathrm{B}$ was takenas the left sacral screw orientation angle called "left pedicle angle"

(Figure 3). The screw orientation plains were shown in a participant with type 1 (Figure 4).

Furthermore, the $C$ point was formed on the vertical line from caudal angle for sacral slope, and the angle between the axial plain joining points C-X-A was called as "caudal 

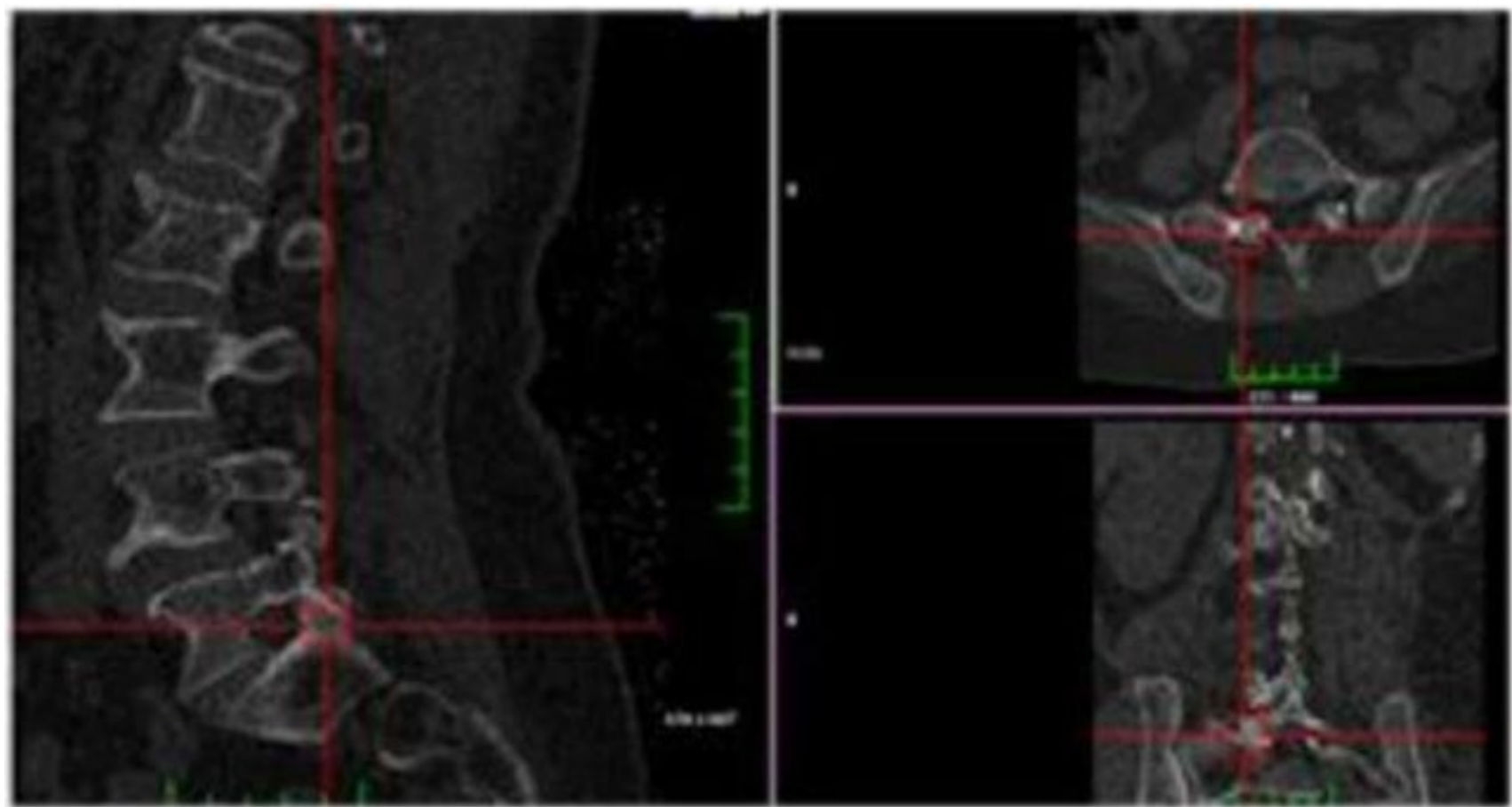

Figure 5. This figure shows the screw entry point in three planes

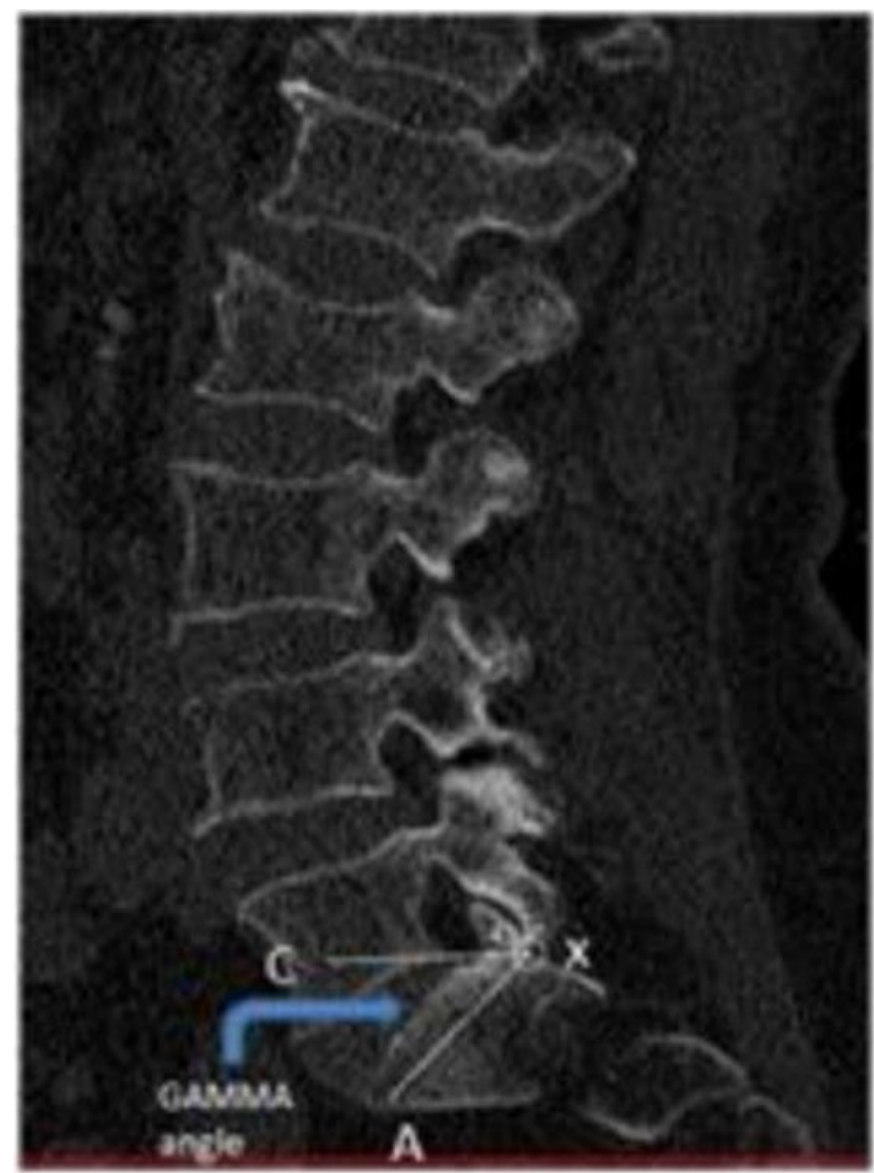

Figure 6. The figure shows the caudal orientation angle of the screw with the blue arrow. (gamma angle- CXA)

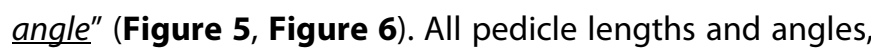
caudal angles and the incidence of PSIS types were measured and recorded properly.

\section{Statistical Analysis}

Statistical analyses were carried out using SPSS for windows 16.0 (SPSS, Inc, an IBM Company, Chicago, Illinois).

The right pedicle length, right pedicle angle and caudal angle values were distributed normally and variations were homogenous between the groups. So, Independent Samples $t$ test was used to describe the statistical differences between the groups, and $p<0.05$ was agreed to be significant. The left pedicle length, left pedicle angle and PSIS type values were not normally distributed and variations were not homogenous among the groups. Therefore, Mann-Whitney $U$ test was used to describe the statistical differences between the groups, and $p<0.05$ was approved to be significant. Additionally, the Wilcoxon Signed Ranks test was used to describe the statistical difference between the right length and left length, right angle and left angle in each the group and $p<0.05$ was considered to be significant. Moreover, the Spearman's correlation tests were used to determine the correlation among th parameters; and $p<0.05$ was accepted as statistically significant.

\section{RESULTS}

A total of 111 patients were included in the study. 58 (52.3\%) male and 53 (47.7\%) female subject were included into this study. The mean age was $46.9 \pm 14.8$ for males and $44.3 \pm 16.4$ for females. In males, the mean value of the right pedicle length was $52.83 \mathrm{~mm}$, and the left pedicle length was $53.81 \mathrm{~mm}$. The right pedicle angle was 35.84 degree and the 
Table 1. This table shows the morphometric analyses results of the males and females participants ( $\mathrm{N}$ : number of the participants; SD: standart deviation)

\begin{tabular}{|c|c|c|c|c|c|c|}
\hline Group & $\mathbf{N}$ & Variable & Minimum & Maximum & $\begin{array}{c}\text { Mean/ } \\
\text { Median (*) }\end{array}$ & SD \\
\hline \multirow{6}{*}{ Female } & 58 & $\begin{array}{l}\text { Rigth } \\
\text { length }\end{array}$ & 42.70 & 62.30 & 52.83 & 4.18 \\
\hline & & Left length & 44.80 & 71 & $54^{*}$ & 4.30 \\
\hline & & Rigth angle & 28.00 & 42.00 & 35.84 & 3.48 \\
\hline & & Left angle & 28.00 & 45 & $34^{*}$ & 4.23 \\
\hline & & $\begin{array}{l}\text { Caudal } \\
\text { angle }\end{array}$ & 22.00 & 59.60 & 39.24 & 6.97 \\
\hline & & PSIS type & 1.00 & 3 & $2^{*}$ & 0.68 \\
\hline \multirow{6}{*}{ Male } & 53 & $\begin{array}{l}\text { Rigth } \\
\text { length }\end{array}$ & 36.60 & 60.40 & 48.88 & 3.90 \\
\hline & & Left length & 41 & 59 & $50^{*}$ & 3.71 \\
\hline & & Rigth angle & 27.00 & 47.00 & 36.47 & 4.18 \\
\hline & & Left angle & 30 & 49 & $36^{*}$ & 3.42 \\
\hline & & $\begin{array}{l}\text { Caudal } \\
\text { angle }\end{array}$ & 24.00 & 57.50 & 38.89 & 6.98 \\
\hline & & PSIS type & 1 & 3 & $1 *$ & 0.49 \\
\hline
\end{tabular}

Table 2. This table shows the distribution of the posterior superior iliac spine (PSIS) types according to the gender

\begin{tabular}{|c|c|c|c|}
\hline Group & PSIS type 1 & PSIS type 2 & PSIS type 3 \\
\hline \multirow{2}{*}{ Female } & 21 & 29 & 8 \\
& $(36.2 \%)$ & $(50.0 \%)$ & $(13.8 \%)$ \\
\hline \multirow{2}{*}{ Male } & 44 & 7 & 2 \\
& $(83.0 \%)$ & $(13.2 \%)$ & $(3.8 \%)$ \\
\hline
\end{tabular}

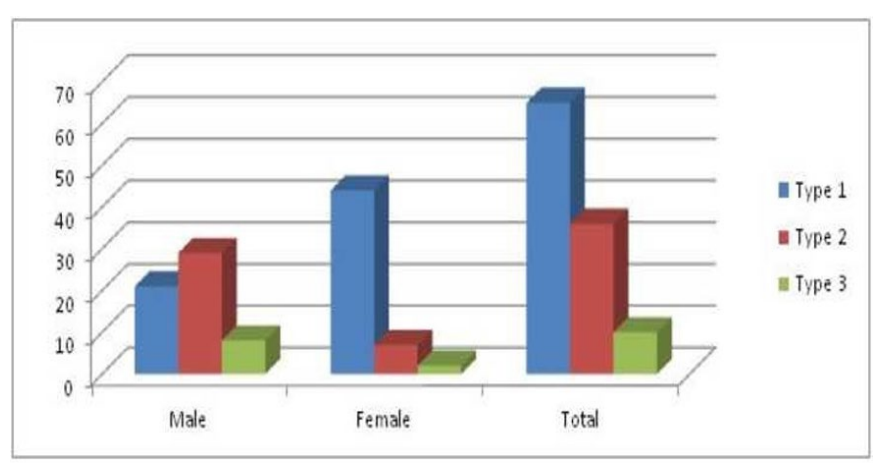

Figure 7. This bar graphic shows the ratio of PSIS types in males, females and total

left pedicle angle was 35.13 degree, and caudal angle was39.24 degree. In females, the right pedicle length was $48.88 \mathrm{~mm}$, left pedicle length was $49.28 \mathrm{~mm}$. The right pedicle angle was 36.47 degree and left pedicle angle was 35.83 degree, and the caudal angle was 39.24 degree (Table 1). PSIS type 1 was seen in 65 (58.6\%) subjects [male: 21 (32.3\%) and female: $44(67.7 \%)$ ]. PSIS type 2 was seen in 36 (32.4\%) individuals [male: 29 (80.6\%); female: 7 (19.4\%)]. PSIS type 3 was seen in 10 (9\%) subjects [male: $8(80 \%)$; female: 2 (20\%)] (Table 2, Figure 7). The statistical test results demonstrated that right pedicle length, left pedicle length and PSIS type values of the female group were different from
Table 3. The values of the right and left pedicle lengths, PSIS type of the males were different than values of the females. The Independent Samples $t$ test; Mann-Whitney $U$ test, $\mathrm{p}<0.05$ ( $\mathrm{t}$ : $\mathrm{t}$ score; Z: Z score)

\begin{tabular}{|c|c|c|c|}
\hline GROUP & Variable & $t / Z^{*}$ & $\mathbf{p}$ \\
\hline \multirow{6}{*}{ Female / Male } & Rigth pedicle length & 5.142 & $<0.001$ \\
\hline & Left pedicle length & $-5.550^{*}$ & $<0.001$ \\
\hline & Rigth pedicle angle & -0.861 & 0.391 \\
\hline & Left pedicle angle & $-0.975^{*}$ & 0.330 \\
\hline & Caudal angle & 0.268 & 0.790 \\
\hline & PSIS type & $-4.852^{*}$ & $<0.001$ \\
\hline
\end{tabular}

Table 4. The values of the right pedicle length and left pedicle length, right pedicle angle and left pedicle angle was not difference between in each the group. The Wilcoxon Signed Rank test, $\mathrm{p}<0.05$ (Z: Z score)

\begin{tabular}{|c|c|c|c|c|}
\hline \multirow{2}{*}{ Variable } & \multicolumn{2}{|c|}{ Female } & \multicolumn{2}{c|}{ Male } \\
\cline { 2 - 5 } & $\mathbf{Z}$ & $\mathbf{p}$ & $\mathbf{Z}$ & $\mathbf{p}$ \\
\hline $\begin{array}{c}\text { Right pedicle length / Left } \\
\text { pedicle length }\end{array}$ & -1.905 & 0.057 & -0.664 & 0.507 \\
\hline $\begin{array}{c}\text { Right pedicle angle / Left } \\
\text { pedicle angle }\end{array}$ & -1.467 & 0.142 & -1.005 & 0.315 \\
\hline
\end{tabular}

the male group values $(t=5.142, p<0.001 ; Z=-5.550, p<0.001$; and $Z=-4.852, p<0.001$, respectively) (Table 3 ).

The Wilcoxon Signed Rank test results revealed that there was no statistical difference between the right pedicle length and left pedicle length, right pedicle angle and left pedicle angle in each the group (Table 4).

The Spearman's correlation test demonstrated that there was a negative correlation between gender and right pedicle length (coefficient $=-0.473, P<0.001$ ); gender and left pedicle length (coefficient $=-0.529, p<0.001$ ); gender and PSIS type (coefficient $=-0.463, p<0.001$ ); left pedicle length and left pedicle angle (coefficient $=-0.276, p=0.003$ ). On the other hand, there was a positive correlation between right pedicle length and left pedicle length (coefficient $=0.720, p<0.001$ ); right pedicle length and PSIS type (coefficient $=0.385$, $\mathrm{p}<0.001) ;$ left pedicle length and PSIS angle (coefficient $=0.247, p=0.009$ ); left pedicle angle and right pedicle angle (coefficient $=0.503, \mathrm{p} 0<0.001$ ) (Table 5).

\section{DISCUSSION}

The most commonly preferred technique in posterior lumbosacral fixation surgery is antero-medial screw orientation. Which still is more popular and safe method, although antero- medial screw orientation has some technical difficulties such as screw penetration to an unsafe region [3-10]. So, to solve these difficulties and provide a strong bio-mechanic fixation and prevent the sacral neurovascular structures from the iatrogenic injury preoperative morphometric analysis of PSIS and sacrum 
Table 5. A negative statistical correlation was found between gender and right pedicle length; gender and left pedicle length; gender and PSIS type; left pedicle length and left pedicle angle. On the other hand a positive correlation was identified between right pedicle length and left pedicle length; right pedicle length and PSIS type; left pedicle length and PSIS angle; left pedicle angle and right pedicle angle. The Spearman's correlation test, $p<0.05$ (CC: Correlation coefficient; RPL: Right pedicle length; LPL: Left pedicle length; LPA: Left pedicle angle; RPA: Right pedicle angle)

\begin{tabular}{|c|c|c|c|c|c|c|c|c|}
\hline & & GENDER & RPL & LPL & LPA & RPA & $\begin{array}{l}\text { PSIS } \\
\text { type }\end{array}$ & \begin{tabular}{|c|} 
Caudal \\
angle
\end{tabular} \\
\hline \multirow{2}{*}{ GENDER } & CC & 1.000 & -0.473 & \begin{tabular}{|l}
-0.529 \\
\end{tabular} & \begin{tabular}{|l|}
0.093 \\
\end{tabular} & 0.073 & \begin{tabular}{|l|}
-0.463 \\
\end{tabular} & -0.040 \\
\hline & $p$ & - & $<0.001$ & $<0.001$ & 0.332 & 0.447 & $<0.001$ & 0.675 \\
\hline \multirow{2}{*}{ RPL } & $C C$ & & 1.000 & 0.720 & -0.281 & -0.113 & 0.385 & 0.038 \\
\hline & $p$ & & - & $<0.001$ & 0.003 & 0.238 & $<0,001$ & 0.691 \\
\hline \multirow{2}{*}{ LPL } & $C C$ & & & 1.000 & -0.276 & \begin{tabular}{|l|}
-0.190 \\
\end{tabular} & 0.247 & -0.020 \\
\hline & $p$ & & & - & \begin{tabular}{|l|}
0.003 \\
\end{tabular} & \begin{tabular}{|l|}
0.045 \\
\end{tabular} & \begin{tabular}{|l|}
0.009 \\
\end{tabular} & \begin{tabular}{|l|}
0.833 \\
\end{tabular} \\
\hline \multirow{2}{*}{ LPA } & $C C$ & & & & \begin{tabular}{|l|}
1.000 \\
\end{tabular} & \begin{tabular}{|l|}
0.503 \\
\end{tabular} & -0.030 & \begin{tabular}{|l|}
-0.093 \\
\end{tabular} \\
\hline & $p$ & & & & - & $<0,001$ & \begin{tabular}{|l|}
0.757 \\
\end{tabular} & \begin{tabular}{|l|}
0.332 \\
\end{tabular} \\
\hline \multirow{2}{*}{ RPA } & $\mathrm{CC}$ & & & & & 1.000 & 0.101 & \begin{tabular}{|l|}
-0.067 \\
\end{tabular} \\
\hline & $p$ & & & & & - & 0.290 & \begin{tabular}{|l|}
0.485 \\
\end{tabular} \\
\hline \multirow{2}{*}{$\begin{array}{c}\text { Sacrum } \\
\text { type }\end{array}$} & $C C$ & & & & & & 1.000 & 0.067 \\
\hline & $p$ & & & & & & - & \begin{tabular}{|l|}
0.483 \\
\end{tabular} \\
\hline \multirow{2}{*}{\begin{tabular}{|c|}
$\begin{array}{c}\text { Caudal } \\
\text { angle }\end{array}$ \\
\end{tabular}} & $\mathrm{CC}$ & & & & & & & \begin{tabular}{|l|}
1.000 \\
\end{tabular} \\
\hline & $p$ & & & & & & & - \\
\hline
\end{tabular}

with its pedicles is more important. Many morphometric analyses reports demonstrated that the antero-medial screw should be oriented with angle of 10-40 degrees, medially. Those reports also identified that frequency of closed type PSIS (called type 2 and type 3) which usually obstruct the antero-medial orientation line and may lead to weak/ false/ insufficient fixation of instrument was seen with a rate of $60 \%$ in males and $40 \%$ in females $[2,6,8,10-13]$. In our study, PSIS type 1 was seen at a rate of $58.6 \%$, type 2 as $32.4 \%$, and type 3 as $9 \%$. Furthermore the rate of incidence of the PSIS type 2 and type 3 was $16.98 \%$ for males and $63.79 \%$ for females. On the other hand, many studies demonstrated that no difference was found between gender and the pedicle length [10,13-17]. In our study, the pedicle screw lengths were statistically different between genders, and the lengths of the males were longer than females. No statistically difference was found between the right and left side pedicle lengths and the pedicle angles in each group. Thus, this study will facilitate the preoperative surgical planning in sacral surgery applications. The averages of the screw orientation angles in present study were similar to other studies in literature. However those studies did not include any data about the angels of screw orientation in the caudal axis while present study could reveal the caudal angle measurements by using of the 3D CT images. Caudal orientation angles were not different between genders in present study. In the absence of gender difference at the opening of the screw, the surgeon will provide preliminary information on preoperative evaluation. In addition, it was determined that the orientation of the screw is not the same for every patient and that the sacral tomography should be taken preop absolutely by knowing the gender difference of the sacral structures for the surgeon.

Correlation test results revealed that there was a negative correlation between gender and right pedicle length, gender and left pedicle length, gender and PSIS type. It can be concluded that males had longer screw lengths than females. They also had open PSIS type comparison of the females. On the other hand, there was a positive correlation between the right pedicle length and left pedicle length, right pedicle length and PSIS type, left pedicle length and PSIS type, left pedicle angle and right pedicle angle. This could mean that screw lengths could increase if the PSIS type score or one side screw length or one side screw orientation angle would increase.

This study has some important disadvantages. Age distribution among genders was not equal. No comparison was made with the patient group to be screened because a robust population was received. The sample distribution was not based on age groups. The scale was assessed separately by 2 specialists, no average difference was observed, and finally, the absence of intra-group and reliability assessments should be indicated as a limitation.

\section{CONCLUSION}

This study, it may be concluded that 3D CT images of the sacrum could help the neurosurgeons to evaluate the anatomy and morphometry of sacrum with its PSIS types, and mean pedicle screw length and pedicle screw orientation angles which are important to provide a strong bio-mechanic fusion and prevent sacral neurovascular structures from the iatrogenic trauma. In this anthropometric study performed with $3 \mathrm{~d}$ bt imaging, comparative studies of patients who underwent surgical operation and healthy individuals could be performed.

\section{DECLARATION OF CONFLICT OF INTEREST}

The author declared no conflicts of interest with respect to the authorship and/or publication of this article.

\section{RESEARCH INVOLVING HUMAN PARTICIPANTS ETHICS APPROVAL}

All procedures performed to subjects according to "the ethical standards of the institutional and/or national 
research committee" and to "the 1964 Helsinki declaration" and its later amendments or comparable ethical standards.

\section{INFORMED CONSENT}

Informed consent was obtained from all individual participants included in the study.

\section{REFERENCES}

1. Ebraheim NA, Xu R, Challgren E. Location of the sacral pedicle, foramina, and ala on the lateral aspect of the sacrum: a radiographic study. Orthopedics 1998; 21: 703-6.

2. Mirkovic S, Abitbol JJ, Steinman J. Anatomic consideration for sacral screw placement. Spine 1991; 16 : 289-94.

3. Morse BJ, Ebraheim NA, Jackson T. Preoperative CT determination of angles for sacral screw placement. Spine 1994; 19: 604-7.

4. Carlson GD, Abitbol JJ, Anderson DR, et al. Screw fixation in the human sacrum. An in vitro study of the biomechanics of fixation. Spine 1992 (Phila Pa 1976) 17: 196-203.

5. Weistroffer JK, Perra JH, Lonstein JE et al. Complications in long fusions to the sacrum for adult scoliosis: minimum five-year analysis of fifty. Spine 2008 (Phila Pa 1976) 33:1478- 1483.

6. Yu BS, Zhuang XM, Zheng ZM, Zhang JF, Li ZM, Lu WW. Biomechanical comparison of 4 fixation techniques of sacral pedicle screw in osteoporotic condition. J Spinal Disord Tech 2010 23: 404-9.

7. Zindrick MR, Wiltse LL, Widell EH, et al. A biomechanical study of intrapeduncular screw fixation in the lumbosacral spine. Clin Orthop Relat Res 1986; 203: 99112.

8. De Peretti F, Argenson C, Bourgeon A, Omar F, Eude P, Aboulker $C$. Anatomic and experimental basis for the insertion of a screw at the first sacral vertebra. Surg Radiol Anat 1991; 13: 133-7.
9. Sae-Jung S, Khamanarong K, Woraputtaporn W, Amarttayakong P. Awareness of the median sacral artery during lumbosacral spinal surgery: an anatomic cadaveric study of its relationship to the lumbosacral spine. Eur Spine J 2014. Doi(:10.1007/s00586-014-3641z).

10. Arman C, Naderi S, Kiray A, et al. The human sacrum and safe approaches for screw placement. J Clin Neurosci 2009; 16: 1046-9.

11. Inoue $M$, Inoue $G$, Ozawa $T$, Miyagi $M$, Kamoda $H$, Ishikawa $T$. L5 spinal nevre injury caused by misplacement of outwardly-inserted S1 pedicle screws. Eur Spine J 2013; 22: 461-5.

12. Robertson PA, Plank LD. Pedicle screw placement at the sacrum: anatomical characterization and limitations at S1. J Spinal Disord 1999; 12: 227-33.

13. Xu R, Ebraheim NA, Mohamed A, el-Gamal H, Yeasting RA. Anatomic considerations for dorsal sacral platescrew fixation. J Spinal Disord1995; 8: 352-6.

14. Kaptanoglu E, Okutan O, Tekdemir I, Beskonakli E, Deda $\mathrm{H}$. Closed posterior superior iliac spine impeding pediculocorporeal S-1 screw insertion. J Neurosurg 2003; 19: 229-34.

15. Abdul-Jabbar A, Yilmaz E, Iwanaga J, et al. Neurovascular relationships of S2 screw placement: Anatomic Study. World Neurosurg 2018 Aug; 116: 108-12. (doi: 10.1016/j).

16. Wang $\mathrm{Y}, \mathrm{Hu}$ W, Hu F, Zhang $\mathrm{H}$, et al. Proper detailed parameters for $\mathrm{S} 1$ sacral alar iliac screw placement in the Chinese population, a 3D imaging study. J Orthop Surg Res 2018 Feb 26; 13: 39. (doi: 10.1186/s13018-018-07398).

17. Jain $\mathrm{N}, \mathrm{Yu}$ E. Intraoperative radiographic technique for visualization of bicortical or tricortical anteromedial sacral screw placement. Clin Spine Surg 2018 Apr; 31: 108-11. (doi: 10.1097/BSD.0000000000000561). 